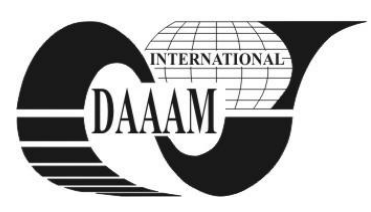

Annals of DAAAM for 2011 \& Proceedings of the 22nd International DAAAM Symposium, Volume 22, No. 1, ISSN 1726-9679 ISBN 978-3-901509-83-4, Editor B. Katalinic, Published by DAAAM International, Vienna, Austria, EU, 2011 Make Harmony between Technology and Nature, and Your Mind will Fly Free as a Bird

\title{
BANK LOAN QUALITY ANALYSIS
}

\author{
IUGA, I[ulia] C[ristina]
}

\begin{abstract}
This article approaches the quality of bank loans. It presents: the causes that lead to a deterioration of loan quality (the increase of nonperforming loans), the methodology of determining nonperforming loans, the indicators that define loan quality, as well as the factors that influence the prevention methods of the deterioration of loan portfolio quality. The paper also contains graphic representations of the quality analysis of loan portfolios in Romania and other European countries (countries from Central and Eastern Europe, as well as European countries with advanced economies).
\end{abstract}

Key words: bank loan quality, nonperforming loans, indicators, analysis, prevention

\section{INTRODUCTION}

Through this work we intend to do a comparative analysis of credit quality of the Romanian banking system, Eastern European countries and advanced economies.

A credit is considered nonperforming when the money given by the bank as a loan has not been reimbursed or whose reimbursement in the future is uncertain.

Nonperforming loans have attracted considerable interest in the literature. While the modeling of the probability of default has been the subject of many studies during the past decades (for a recent contribution on bank loans, see Bonfim, 2009), a thriving literature on recovery rates only emerged recently, with the advent of the new Basel Capital Accord (see Bastos, 2010). The geographic origins of empirical studies on bank loan recoveries include the Europe (Dermine and Neto de Carvalho, 2006; Caselli et al., 2008; Grunert and Weber, 2009; Calabrese and Zenga, 2010) . Because loans are private instruments, few data is publicly available to researchers.

\section{LOAN QUALITY}

Loan quality has a close inverse correlation with nonperforming loans: the lower is the number of nonperforming loans; the higher is the quality of the loans. Loan quality cannot be studied without considering nonperforming loans. The major cause of problems regarding the inability to pay back loans and of the quality drop is related to:

$>\quad$ the standards of loan;

$>\quad$ poor management of the loan portfolio;

$>$ A lack of attention to changes in the economic circumstances, which may lead to a deterioration of the loans granted by the bank.

The indicators that define loan portfolio quality in Romania have seen a worsening in the last two years, the main causes being: - the economic recession; - rising unemployment; currency devaluation; - the high level of interest in loans.

In the classification process of the loan portfolio for the clients in the non-banking sector, Regulation no. 3/2009 of the National Bank of Romania regarding the classification of loans and investments imposes the following classification: $\underline{\text { Standard }}$ loans - are the investments that don't involve risks in the management of the debt and are granted to reliable clients for good businesses; Loans under observation - are the loans granted to clients with excellent financial results, but who face challenges in paying the due instalments and the associated interests for short periods of time; Substandard loans - are the investments with clear deficiencies and risks, which endanger the liquidation of debt, being insufficiently protected by the net value of the capital and / or by the borrower's ability to pay; Doubtful loans - their full repayment is highly uncertain due to existent conditions, values and collaterals, being practically unprotected or protected very little by the achievable value of the collateral; Losing loans are the loans that can't reimbursed to the bank.

Within the classification process of the loan portfolio for borrowers from outside loan institutions, banks apply simultaneously the following criteria: a) debt service; b) financial performance; c) initiating legal proceedings; d) unmaking by contamination.

In the case of nonperforming loans, a special attention is given to "debt service" outstanding if it is past due by 90 days or if legal proceedings against the borrower have been initiated. The 90 days criterion is used more often by various national legislations in order to define a nonperforming loan. In the "Financial Soundness Indicators: Compilation Guide", the International Monetary Fund mentions that nonperforming claims are "the loans or assets whose principal or interest are three months or more (90 days or more) in arrears".

\section{THE METHODOLOGY OF DETERMINING NONPERFORMING LOANS}

The prudential methodology of determining nonperforming claims is different from the accounting methodology because of two elements:

1. The classification criteria:

$>$ The accounting methodology takes into account two criteria: (a) debt service; (b) initiating legal proceedings against the borrower

$>$ The prudential methodology uses four criteria: (a) debt service; (b) initiating legal proceedings against the borrower; (c) financial performance of the borrower; (d) unmaking by contamination at the level of the borrower.

2. The volume of the outstanding loan:

$>$ the accounting methodology takes into consideration only the actual arrears (overdue instalments) - the instalments that are due in the future are considered current;

$>$ The prudential methodology takes into account the entire balance of the loan and of the associated interests, regardless of the late instalments.

\section{INDICATORS THAT DEFINE LOAN QUALITY}

The most important indicators that define loan quality are: a) outstanding and doubtful loans granted to customers (gross value), expressed as a ratio of total loan portfolio (at gross 
value); b) outstanding and doubtful loans granted to customers (net value), expressed as a ratio of total loan portfolio (at net value); c) outstanding and doubtful claims (net value) expressed as ratio of total bank assets; d) outstanding and doubtful claims (net value) expressed as ratio of equity capitals.

The gross value is the accounting value. The net value is calculated as a difference between outstanding and doubtful loans granted to customers at gross value and the loan risk provisions associated with them.

\section{THE ANALYSIS OF THE LOAN PORTFOLIO QUALITY IN ROMANIA}

The adverse effect of economic slowdown, of rising inflation and of the currency's depreciation was acutely felt in late 2008 and in the first months of 2009 due to the significant deterioration of the banks' loan portfolio quality. The volume of outstanding and doubtful loans (gross value) tripled in 2009 compared to 2008. The percentage of outstanding and doubtful loans granted to customers out of the total loan portfolio (at gross value) followed the same trend, reaching $4 \%$ in December 2009 and $5.9 \%$ at the end of the second semester in 2010 .

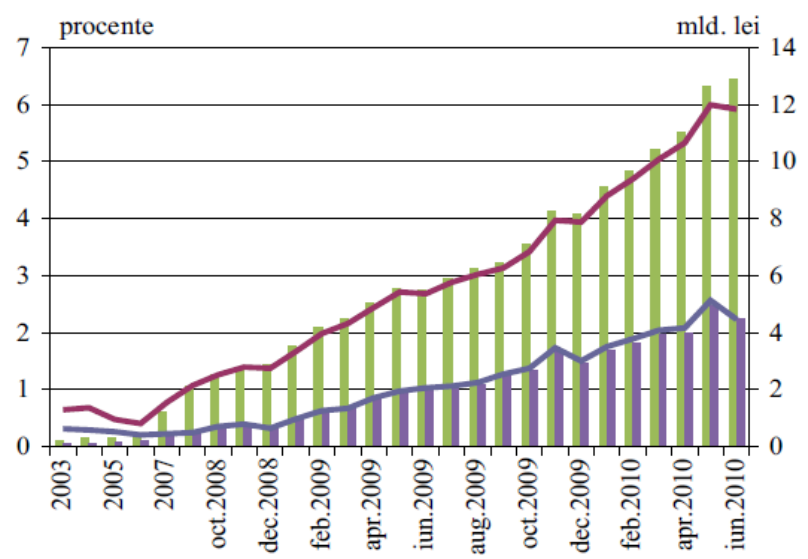

Fig. 1. Loan quality in the Romanian banking system

Outstanding and doubtful loans granted to customers (gross value)

Outstanding and doubtful loans granted to customers (net value)

Outstanding and doubtful loans granted to customers (net value) / total loan portfolio (net value)

- Outstanding and doubtful loans granted to customers (gross value) / total loan portfolio (gross value)

\section{THE ANALYSIS OF THE LOAN PORTFOLIO QUALITY IN EUROPEAN COUNTRIES}

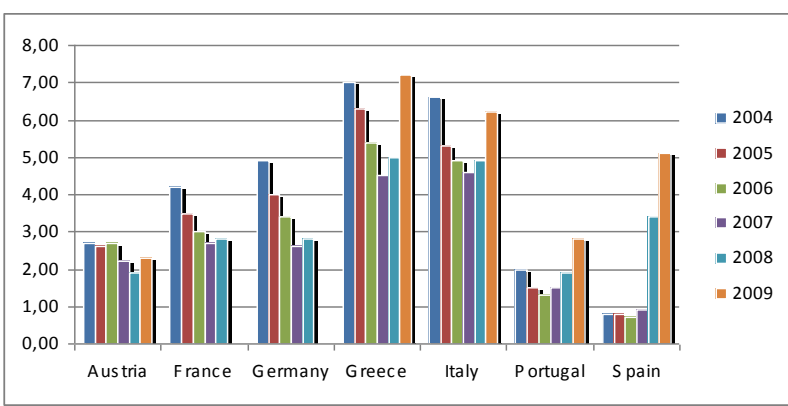

Fig. 2. Loan portfolio quality in the advanced European economies (Bank nonperforming Loans to Total Loans)

Nonperforming loans (NPLs) have increased substantially in the Central and Eastern Europe (CEE) region since the onset of the global financial crisis. The negative trend recorded by the quality of the loan portfolio, as an effect of the global financial crisis and economic recession, is common for many developed and developing countries in the European Union.

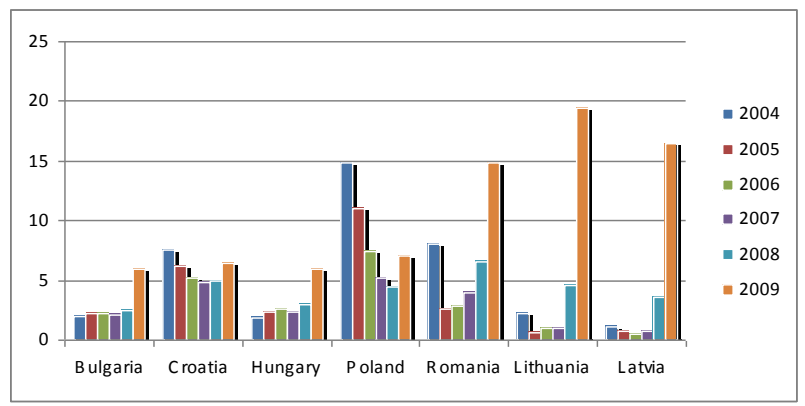

Fig. 3. Loan portfolio quality in Central and Eastern Europe

A positive aspect for Romania is the nonexistence of toxic assets in the accounting balances of loan institutions, as well as the fact that no bank filed for bankruptcy. The factors that influence the prevention methods for the deterioration of loan portfolio quality are: the early detection of the deterioration potential of the quality of the clients in the portfolio; the bank's management; the availability and quality of collateral; the bank's marketing and development strategies.

\section{CONCLUSION}

The analysis of the three figures show that in 2009 (compared to previous years of each country) the share of nonperforming loans in total loans increased in all European countries whether is countries with economies advanced or Eastern European countries. This phenomenon manifested itself amid the global financial crisis. However, European countries with advanced economies have managed to maintain this low percentage of nonperforming loans (Spain, 5\%, Austria and Portugal - fewer than 3\%) in the middle of the financial crisis. Central and Eastern Europe countries with the highest percentage of bad loans are: Romania, Latvia and Lithuania.

\section{REFERENCES}

Bastos Joao (2010). A Forecasting bank loans loss-givendefault. Journal of Banking \& Finance, vol. 34, pg. 25102517, ISSN 0378-4266

Bonfim, D. (2009). Credit risk drivers: evaluating the contribution of firm level information and of macroeconomic dynamics. Journal of Banking and Finance, vol. 33, pg. 281-299, ISSN 0378-4266

Calabrese,R.,Zenga,M.(2010).Bank loan recovery rates: measuring and nonparametric density estimation. Journal of Banking and Finance,vol. 34,pg. 903-911,ISSN 0378-4266

Caselli, S., Gatti, S., Querci, F. (2008). The sensitivity of the loss given default rate to systematic risk: new empirical evidence on bank loans. Journal of Financial Services Research, vol. 34, pg. 1-34, ISSN: 1573-0735

Dermine, J., Neto de Carvalho, C. (2006). Bank loan lossesgiven-default: a case study. Journal of Banking and Finance, vol. 30, pg. 1243-1291, ISSN 0378-4266

Foos D, Norden L. \& Weber M. (2010). Loan growth and riskiness of banks. Journal of Banking \& Finance, Vol. 34, (June 2010) pg. 2929-2940, ISSN 0378-4266.

Grunert, J., Weber, M. (2009). Recovery rates of commercial lending: empirical evidence for German companies. Journal of Banking and Finance vol. 33, pg. 505-513, ISSN 0378-4266

*** (2010) http://www.imf.org - International Monetary Fund, Global Financial Stability Report, Accessed on: 2010-12-10

*** (2010) http://www.bnr.ro - National Bank of Romania, Financial Stability Report, and Accessed on: 2010-12-10 